\title{
Preparation of Nano-Sized Mesoporous Silica and Its Application in Immobilization of $\beta$-galactosidase from Aspergillus Oryzae
}

\author{
Jiao Yang ${ }^{1}$, Zhenzhen Liu ${ }^{1}$, Huan $\mathrm{Ge}^{1}$, Sufang Sun ${ }^{1}$ \\ ${ }^{1}$ College of Chemistry and Environmental Science, Hebei University, Baoding, China \\ Correspondence: Sufang Sun, College of Chemistry and Environmental Science, Hebei University, Baoding, China. \\ E-mail: hebeiborate@163.com
}

Received: November 11, 2016

Accepted: December 13, 2016 Online Published: January 14, 2017

doi:10.5539/ijc.v9n1p65

URL: http://dx.doi.org/10.5539/ijc.v9n1p65

\begin{abstract}
In alkaline conditions, monodisperse nano-sized mesoporous silica was synthesized using cetyl trimethyl ammonium bromide (CTAB) as template and tetraethoxysilane (TEOS) silica as source in ethanol / water cosolvent conditions. Using method of nitrogen adsorption, specific surface area of the dried monodisperse nano-sized mesoporous silica was about $1591 \mathrm{~m}^{2} / \mathrm{g}$ and the pore size was about $3.8 \mathrm{~nm}$. The field-emission scanning electron microscope (SEM) micrographs showed that the silica particles obtained were spherical with an approximate diameter of $160 \mathrm{~nm}$ and of good dispersion. Transmission electron microscopy (TEM) revealed that the carrier had an excellent cellular structure with disordered multi-channels and smooth surface. The nano-sized mesoporous silica above was employed to immobilize $\beta$-galactosidase from aspergillus oryzae for the first time. At the experimental conditions in section 2.4 , the enzyme activity and the activity yield were $535.11 \mathrm{U} / \mathrm{g}$ dry carrier and $79.63 \%$, respectively. Kinetic data of the immobilized enzyme such as optimum temperature, $\mathrm{pH}$, and thermal and $\mathrm{pH}$ stability among other valuable results were also determined.
\end{abstract}

Keywords: nano-sized mesoporous silica, immobilization, $\beta$-galactosidase, CTAB, TEOS

\section{Introduction}

In 1990s, many researches showed the possibility of synthesizing pore-size distribution of uniform nano-sized mesoporous silica particles using appropriate surfactants such as template agent (He et al., 2009; Zhu et al., 2013). Various effective methods for synthesizing nanomaterials such as hydrothermal reaction, room temperature synthesis, microwave radiation synthesis, precipitation synthesis and sol-gel synthesis have been documented (Zhang et al., 2001; Zhao et al., 1999). The quantities of the mesoporous nanomaterials are diffrenet when the experimental environments are varied (Kresge et al., 1992; Beck et al., 1992; Huang \& Kruk, 2015). Among them, more attention has been paid to the synthesis of well-defined mesoporous silica spheres, because their applications are very promising in chromatography, catalysis, cosmetics, and photonic crystals (Huo et al., 1997; Grün et al., 1997; Qi et al., 1998; Boissiere et al., 2001; Kosuge \& Singh, 2001; Kosuge et al., 2003; Kosuge et al., 2004). However, there were few reports on the solution synthesis of monodisperse mesoporous silica spheres with nanometer-sized diameters (Yang et al., 2006).

In this study, monodisperse nano-sized mesoporous silica was synthesized in aqueous methanol using cetyl trimethyl ammonium bromide (CTAB) as template and tetraethoxysilane (TEOS) as silica source. Its surface area and pore size were determined by using nitrogen adsorption method. The diameter and structure of the spheres were characterized by the field-emission scanning electron microscope (SEM) and transmission electron microscopy (TEM). The silica spheres obtained were initially used to immobilize $\beta$-galactosidase ( $\beta$-D-galactosidase galactohydrolase, EC 3.2.1.23) from aspergillus oryzae (Bayramoğlu et al., 2005). At the experimental conditions, the enzyme activity and the activity yields were obtained. Similarly, the kinetic data such as temperature and $\mathrm{pH}$ optima, thermal and $\mathrm{pH}$ stabilities were tested and compared with those of the free enzyme. Finally, the operational stability of the immobilized enzyme was investigated.

\section{Experiment}

\subsection{Reagents and Apparatus}

Reagents: All materials were of analytical grade and were used without any further purification. Cetyl trimethyl ammonium bromide (CTAB, Sigma-Aldrich Co. Ltd.), $\beta$-galactosidase (From aspergillus oryzae, Sigma-Aldrich Co. 
Ltd.), O-nitrophenyl- $\beta$-D-galactopyranoside (ONPG, $>$ 99.0\%, Bio Basic Inc.), Sodium Cyanoborohydride (95.0\%, Shanghai Macklin Biochemical Co. Ltd.), Glutaraldehyde ( $\geq 50.0 \%$, Tianjin Kemiou Chemical Reagent Co. Ltd.), Diethanolamine ( $\geq 99.0 \%$, Tianjin Kemiou Chemical Reagent Co. Ltd.) and HCl (37\%, Tianjin Kemiou Chemical Reagent Co. Ltd.) were used as received.

Apparatus: Ultraviolet Visible Spectrophotometer (T6 New Century), Vacuum Pump with Circulated Water System (SHZ-D (III)), Digital pH Meter (PHS-3C), Vacuum Desiccator (DZF-6020), Water Constant Temperature Oscillator (SHA-B), Magnetic Hotplate-Stirrer with Timer (MS-H-Pro ${ }^{\mathrm{T}}$ ), Scanning Electron Microscope (JSM-7500) and Transmission electron microscope (Tecnai G2 F20 S-TWIN) were used.

\subsection{Preparation of Nano-sized Mesoporous Silica Spheres}

Monodisperse nano-sized mesoporous silica was synthesized by aqueous methanol (Meng et al., 2009; Trofimova et al., 2012). $3.9400 \mathrm{~g}$ of Cetyl trimethyl ammonium bromide (CTAB) was weighed and dissolved in $800 \mathrm{~g}$ of aqueous methanol $(40 \%)$, then $2.3 \mathrm{~mL}$ of sodium hydroxide solution $(1.0 \mathrm{~mol} / \mathrm{L})$ was added into it. After the solution was stirred for 30 minutes, $1.3 \mathrm{~mL}$ of TEOS was slowly dropped and the mixture was stirred overnight at room temperature. The precipitate was collected and washed sufficiently with distilled water and ethanol, and then it was put into round-bottom flask which had $20 \mathrm{~mL}$ of ethanol and $4 \mathrm{~mL}$ of concentrated hydrochloric acid and heated to reflux at $80{ }^{\circ} \mathrm{C}$ for $24 \mathrm{~h}$ in order to remove the template agent (Anderson et al., 1998). The solid particles, the nano-sized mesoporous silica spheres, were obtained by centrifugation, fully washed with deionized water and dried at $60{ }^{\circ} \mathrm{C}$ under vacuum.

\subsection{Preparation of the Activated Nano-sized Mesoporous Silica Spheres}

$3.0000 \mathrm{~g}$ of nano-sized mesoporous silica spheres were weighed and put into the solution of $60.0 \mathrm{~mL}$ toluene and 4.5 $\mathrm{mL}$ aminopropyl triethoxysilane. The mixture was refluxed with constant stirring at $110{ }^{\circ} \mathrm{C}$ for $12 \mathrm{~h}$ in a nitrogen atmosphere (Zhang et al., 2007). Then, the solid particles, i.e. the amino mesoporous silica, were obtained by centrifugation, washed with toluene and acetone thoroughly, and dried for $12 \mathrm{~h} \mathrm{at} 80^{\circ} \mathrm{C}$ vacuum, then put in a desiccator to be used in the next step.

Then, with $2.0 \mathrm{~mL}$ glutaraldehyde $(25 \%)$ and $8.0 \mathrm{~mL}$ diethanolamine mixed together and stirred for 30 minutes at $20^{\circ} \mathrm{C}$, $1.0000 \mathrm{~g}$ amino silica obtained above was added (Tu et al., 1999), the precipitate was obtained with constant stirring for $4 \mathrm{~h}$ at $30^{\circ} \mathrm{C}$, after being washed completely with distilled water, it was put into $\mathrm{HCl}$ solution $(0.1 \mathrm{~mol} / \mathrm{L})$. The activated mesoporous silica was obtained after 30 minutes with stirring. After being washed with distilled water and dried at 60 ${ }^{\circ} \mathrm{C}$, it was stored to be used later.

\subsection{Immobilization of $\beta$-galactosidase}

$0.0500 \mathrm{~g}$ of the activated nano-sized mesoporous silica spheres as carriers was put into $0.5 \mathrm{~mL} \beta$-galactosidase solution $(4.0 \mathrm{mg} / \mathrm{mL}$, prepared with $0.1 \mathrm{~mol} / \mathrm{L}$, pH 5.0 phosphate buffer), and process was carried out in the Water Constant Temperature Oscillator at $35^{\circ} \mathrm{C}$ for $4 \mathrm{~h}$. The immobilized enzyme was then filtered and washed with distilled water to wash the excess of $\beta$-galactosidase.

\subsection{Activity Assay of $\beta$-galactosidase}

The activities of the free and the immobilized enzyme were determined using ONPG $(1.5 \mathrm{mg} / \mathrm{mL}$ ) as the substrate (Jun et al., 2000). For the activity of free enzyme, the free enzyme $(0.1 \mathrm{~mL})$ was added to the phosphate buffer $(\mathrm{pH} 6.0,0.1 \mathrm{~mol} / \mathrm{L}$, $0.9 \mathrm{~mL})$. Then ONPG $(1.5 \mathrm{mg} / \mathrm{mL}, 0.2 \mathrm{~mL})$ was added to the mixture. After incubating at $55^{\circ} \mathrm{C}$ for 15 minutes, the reaction was stopped by adding $\mathrm{Na}_{2} \mathrm{CO}_{3}$ solution $(1.0 \mathrm{~mol} / \mathrm{L}, 2.0 \mathrm{~mL})$, and the amount of ONPG was measured directly at $405 \mathrm{~nm}$. For the activity of immobilized enzyme, the immobilized enzyme $(0.0500 \mathrm{~g})$ was added to the phosphate buffer $(0.1 \mathrm{~mol} / \mathrm{L}$, $\mathrm{pH}$ 6.0, $1.0 \mathrm{~mL}$ ). The reaction was carried out and analyzed as above. All activity assays were repeated three times.

One unit (1U) of $\beta$-galactosidase activity was defined as the amount of enzyme that released $1 \mu$ mol ONPG in 1 minute at $55{ }^{\circ} \mathrm{C}$. The activity yield was calculated as the ratio of immobilized enzyme activity to the total enzyme activity subjected to immobilization, which can be expressed by the equation (1):

$$
\text { The enzyme activity yield }(\%)=\frac{\text { immobilize enzyme activity }}{\text { the total enzyme activity subjected to immobilization }}
$$

\subsection{Operational Stability}

The operational stability of the immobilized enzyme was determined according to the following procedures. $0.0500 \mathrm{~g}$ of the immobilized enzyme was taken and soaked in $1.8 \mathrm{~mL}$ phosphate buffer overnight. After the mixture was incubated at $55^{\circ} \mathrm{C}$ for 15 minutes, the reaction was initiated by adding $0.2 \mathrm{~mL} 1.5 \mathrm{mg} / \mathrm{mL} \mathrm{ONPG}$, and then the reactive mixture was analyzed as above. Afterward, the solid was filtered and washed thoroughly with distilled water and the above experiment was repeated under the same conditions. 


\section{Results and Discussion}

\subsection{Morphology of Nano-sized Mesoporous Silica Particles}

Scanning electron microscopy (SEM) was used to characterize the surface structures and the diameters of the silica spheres and the results were illustrated in Figure 1. The measured diameter of the mesoporous silica particle from the figure was about $160 \mathrm{~nm}$. As is also revealed in Figure 1, the mesoporous silica particles have an excellent dispersibility. Transmission electron microscopy (TEM) had also been done in order to determine the structures of the silica particles obtained. Results in Figure 2 showed that a cellular structure with disordered multi-channels was found in the mesoporous silica, which would be very beneficial to immobilize the enzyme due to the increase in the surface area (Bayramoğlu et al., 2005).

\subsection{Surface Area and Pore Size of Mesoporous Silica Particle}

As shown in Figure 3, nitrogen adsorption-desorption linear isotherms of mesoporous materials obtained from Quantachrome Instruments version 3.01 were typical Langmuir isotherm of type IV having H3 hysteresis loop (Liang et al., 2014), which indicated the presence of disordered mesopores.

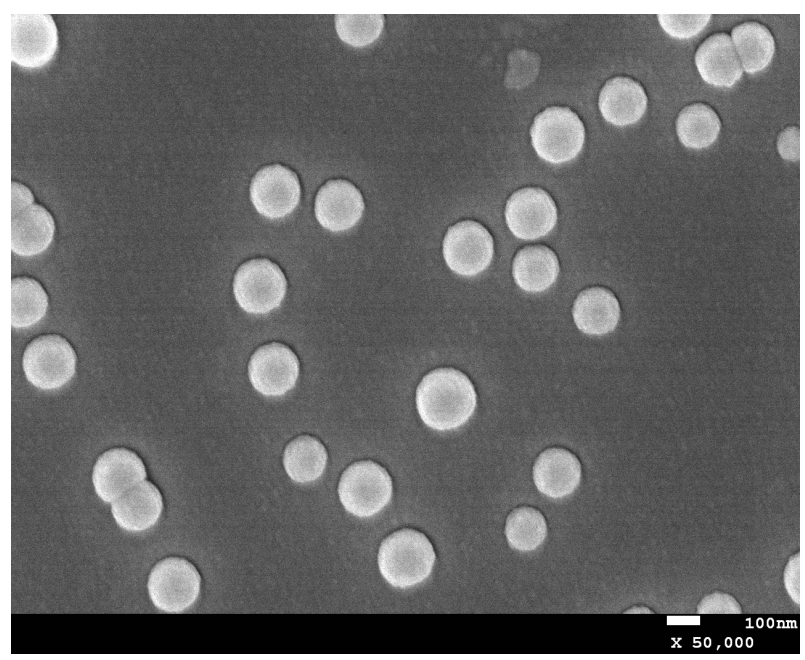

Figure 1. Scanning electron microscope image of nano-sized mesoporous silica

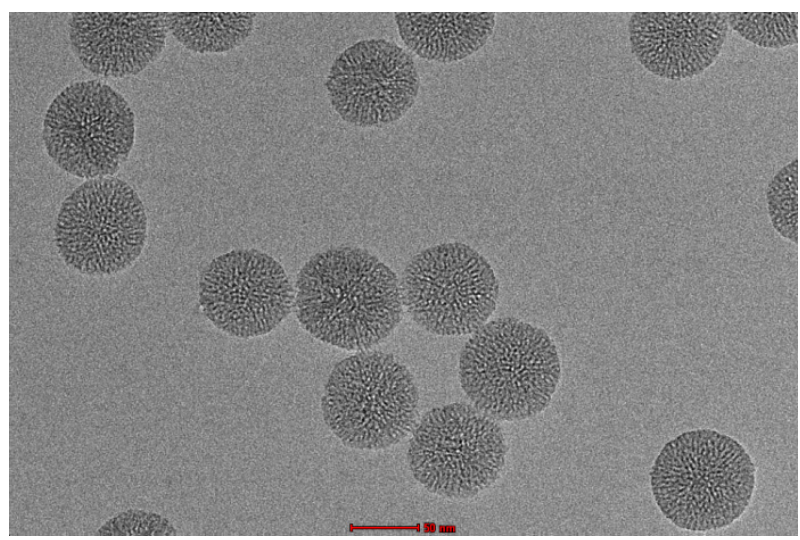

Figure 2. Transmission electron microscopy photograph of nano-sized mesoporous silica 


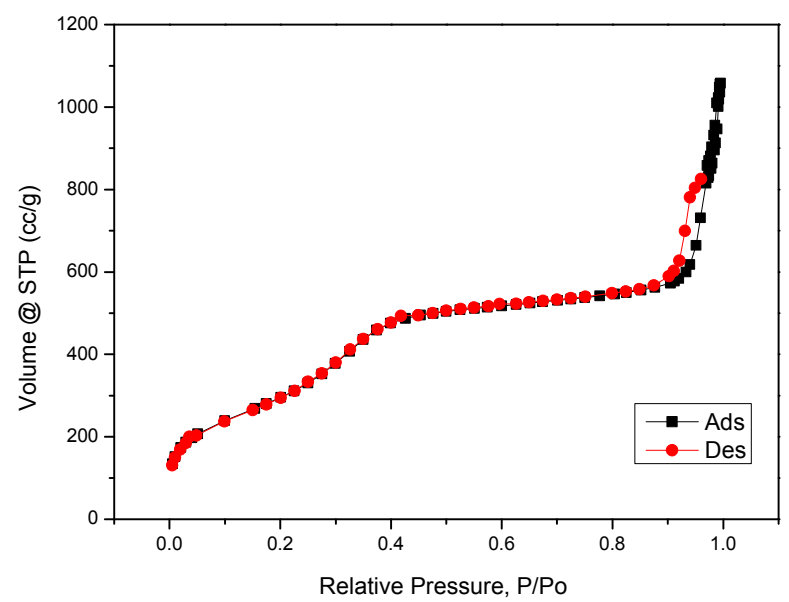

Figure 3. Nitrogen adsorption desorption linear isotherms of mesoporous materials at $77 \mathrm{~K}$

The pore size distribution was determined by DFT method. As shown in Figure 4, a peak appeared at the pore width of $3.8 \mathrm{~nm}$, which means the mainly existing pore size of the synthetic mesopores silica was about $3.8 \mathrm{~nm}$ in diameter.

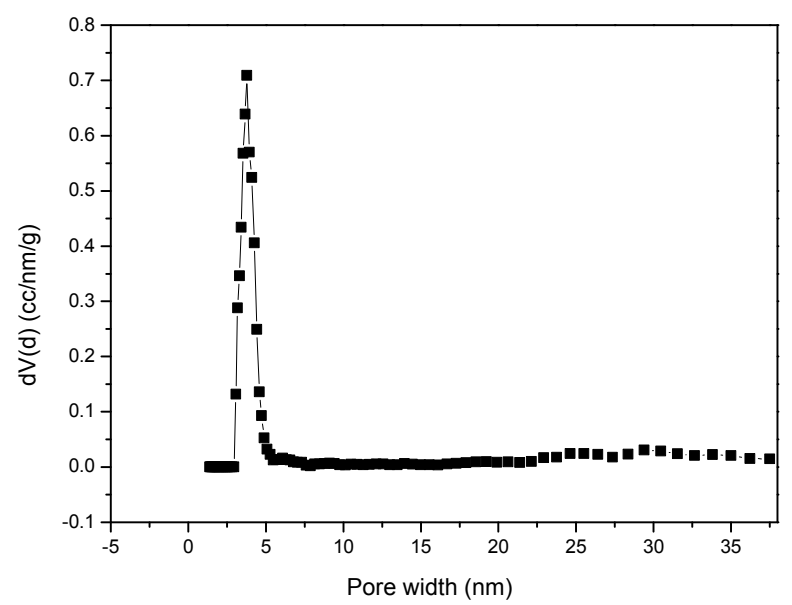

Figure 4. Pore size distribution of synthetic mesoporous materials by DFT method at $77 \mathrm{~K}$

According to Multi-Point BET Plot (Figure 5), the BET surface area was calculated by Quantachrome Instruments Version 3.01 using equation (2) (Fagerlund, 1973):

$$
\frac{1}{X\left(p_{0} / p-1\right)}=\frac{1}{X_{m} C}+\frac{C-1}{V_{m} C}\left(\frac{p}{p_{0}}\right)
$$

Therein, $X$ is the total mass of the adsorbed gas per unit gram carrier at adsorption equilibrium when the gas pressure is $p, X_{m}$ is the total mass of the adsorbed gas per gram carrier when its surface is fully covered by a single molecular layer, $p_{0}$ is the saturated vapor pressure of nitrogen at $77 \mathrm{~K}$, and $C$ is the adsorption coefficient.

According to Figure 5 and Equation (2), $X_{m}$ could be determined and its value can be substituted into equation (3) (Fagerlund, 1973):

$$
S_{B E T}=\frac{X_{m}}{M} N A m
$$

Therein, $M$ is the molecular weight of adsorbate, $N$ is Avogadro's number and $A_{m}$ is the cross-sectional area of nitrogen and its value is $1.62 \times 10^{-19} \mathrm{~m}^{2}$ at $77 \mathrm{~K}$.

The specific surface area calculated for nano-sized mesoporous silica particles according to equation (3) was $1591 \mathrm{~m}^{2} / \mathrm{g}$. 


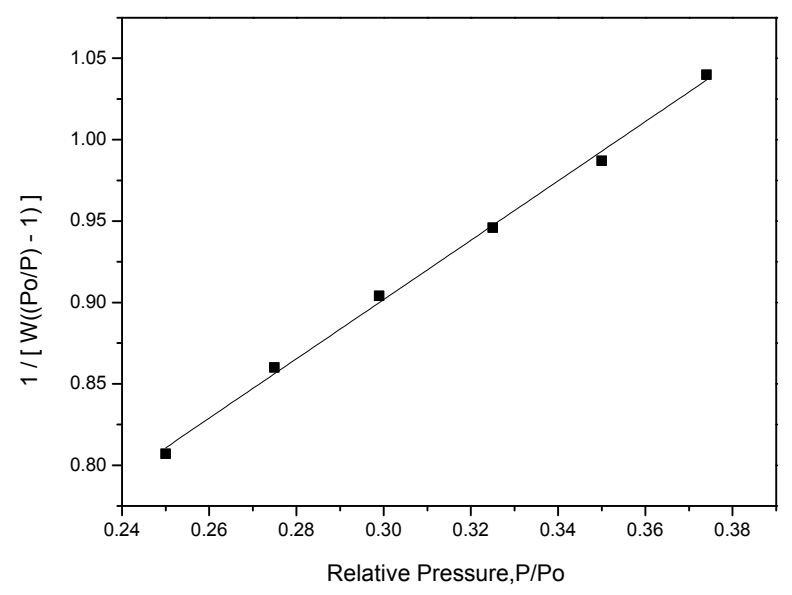

Figure 5. Multi-Point BET Plot of mesoporous materials at $77 \mathrm{~K}$

\subsection{Enzyme Activity and the Activity Yield}

In the experimental conditions listed in section $2.3, \beta$-galactosidase from aspergillus oryzae was immobilized on the nano-sized mesoporous silica obtained. The enzyme activity and the activity yield determined were $535.11 \mathrm{U} / \mathrm{g}$ dry carrier and $79.63 \%$, respectively.

\subsection{Properties of the Immobilized $\beta$-galactosidase}

\subsubsection{Optimum Temperature and Thermostability}

In Figure 6, the enzyme activities were determined by ONPG as a substrate at temperature range of $40-65^{\circ} \mathrm{C}$ at $\mathrm{pH}$ of 5.0 for 15 minutes. The results showed that the optimum temperature for free enzyme and immobilized enzyme is 55 ${ }^{\circ} \mathrm{C}$.

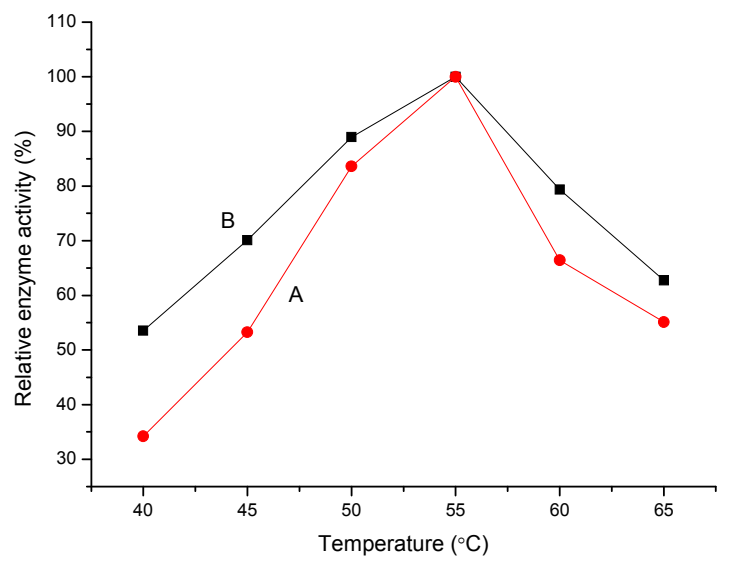

Figure 6. Effect of temperature on the activity of free and immobilized enzyme (A: free enzyme; B: immobilized enzyme)

The thermal stabilities of the free and immobilized enzyme were measured at $50{ }^{\circ} \mathrm{C}$ and $60^{\circ} \mathrm{C}$, respectively. After $8 \mathrm{~h}$ at $50{ }^{\circ} \mathrm{C}$, the remaining activity of the free enzyme was $49.81 \%$ and the immobilized enzyme was $52.63 \%$. After 80 minutes at $60{ }^{\circ} \mathrm{C}$, the residual activity of the former was $19.88 \%$ and the latter was $25.15 \%$. So the residual activity of the immobilized enzyme was slightly higher than the free enzyme in $50{ }^{\circ} \mathrm{C}$ or $60{ }^{\circ} \mathrm{C}$, and the conclusion was in agreement with the reference (Tanriseven \& Doğan, 2002).

\subsubsection{Optimum $\mathrm{pH}$ and $\mathrm{pH}$ Stability}

The enzyme activities were tested at $55{ }^{\circ} \mathrm{C}$ for 5 minutes in various $\mathrm{pH}$ ranging from 3.0 to 8.0. The experimental data indicated that both free and immobilized enzyme attained their maximum activities (100\%) in pH 6.0. 


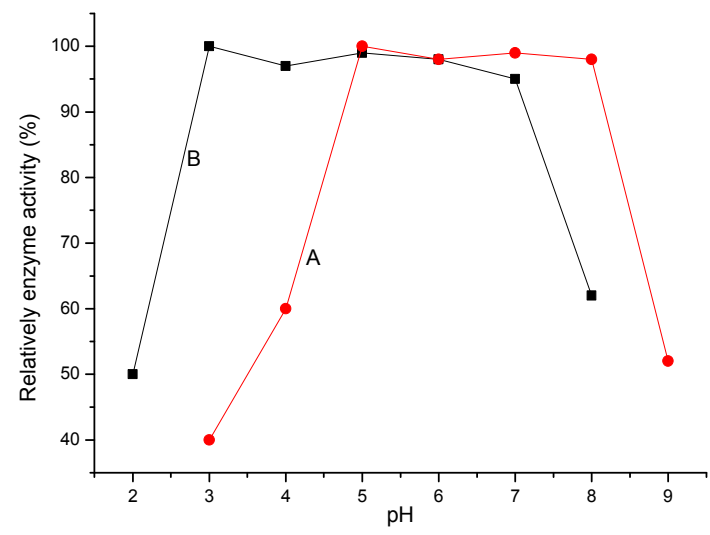

Figure 7. The PH stability of free and immobilized enzyme (A: free enzyme; B: immobilized enzyme)

The $\mathrm{pH}$ stabilities of the enzymes were also determined by changing the $\mathrm{pH}$ of the phosphate buffer. The results in Figure 7 described that the free enzyme was very stable in the $\mathrm{pH}$ range of 5.0-8.0, while that of the immobilized enzyme were 3.0-7.0, the data showed that the acid resistance of immobilized enzyme was greatly improved, but its activity decreased greatly when $\mathrm{pH}>7.0$, this could be caused by the instability of the silica gel in the base.

\subsection{Operational Stability}

The experiment was repeated five times by using the procedures mentioned in section 2.6 with the same immobilized enzyme at the same initial concentration of ONPG. In Table 1, all of the measurements of the enzyme activity were almost identical and the maximum deviation was $0.5 \%$. The results showed that there is no insignificant decrease for activity of immobilized enzyme after being used five times, which means that almost no enzyme fell off from the nano-sized mesoporous silica (Sun et al., 1999). Therefore, the immobilized enzyme had a good operational stability.

Table 1. Enzyme activity and recovery rate of immobilized $\beta$-galactosidase for five times

\begin{tabular}{llllll}
\hline Times & 1 & 2 & 3 & 4 & 5 \\
\hline Activity yield (\%) & 100 & 99.9 & 99.7 & 99.6 & 99.5 \\
\hline
\end{tabular}

\section{Conclusion}

In this paper, the monodisperse, nano-sized mesoporous silica was synthesized in methanol aqueous solution with CTAB as template and TEOS as silica source. Scanning electron microscopy (SEM) micrographs showed that the diameter of the silica material obtained was about $160 \mathrm{~nm}$. Nooney et al (Nooney, et al., 2002) discovered that the diameter of the silica material obtained was $740 \mathrm{~nm}$, the discrepancy may be brought due to the dosage of ammonium hydroxide or the different experimental conditions, which need to be further verified. In addition, a cellular structure with disordered multi-channels was also presented by transmission electron microscope (TEM). The specific surface area of the mesoporous silica was about $1591 \mathrm{~m}^{2} / \mathrm{g}$ and the pore size was about $3.8 \mathrm{~nm}$ by nitrogen adsorption isotherm. At the experimental conditions, $\beta$-galactosidase from aspergillus oryzae was immobilized on carrier above and the enzyme activity and the activity yield determined were $535.11 \mathrm{U} / \mathrm{g}$ dry carrier and $79.63 \%$, respectively. Kinetic data determined from the immobilized enzyme were as follows: the optimal temperature and $\mathrm{pH}$ was $55^{\circ} \mathrm{C}$ and 5.0 , separately, and the activity was very stable when $\mathrm{pH}$ ranged from 3.0 to 7.0 , the thermal stability of the immobilized was slightly better than that of the free enzyme. Operational stability revealed that almost no enzyme fell off after being used five times. Considering all the facts described above, the nano-sized mesoporous silica, which has a great specific surface area, is potential to immobilize enzyme and needs to be further studied.

\section{References}

Anderson, M. T., Martin, J. E., Odinek, J. G., \& Newcomer, P. P. (1998). Surfactant-Templated Silica Mesophases Formed in Water: Cosolvent Mixtures. Chemistry of Materials, 10(1), 311-321. http://dx.doi.org/10.1021/cm9704600

Bayramoğlu, G., Kaya, B., \& Arica, M. Y. (2005). Immobilization of Candida rugosa lipase onto spacer-arm attached poly (GMA-HEMA-EGDMA) microspheres. Food Chemistry, 92(2), 261-268. http://dx.doi.org/10.1016/j.foodchem.2004.07.022

Beck, J. S., Vartuli, J. C., Roth, W. J., Leonowicz, M. E., Kresge, C. T., Schmitt, K. D., .. Schlenker, J. L. (1992). A new family of mesoporous molecular sieves prepared with liquid crystal templates. Journal of the American Chemical Society, 114(27), 10834-10843. http://dx.doi.org/10.1021/ja00053a020 
Boissiere, C., Kümmel, M., Persin, M., Larbot, A., \& Prouzet, E. (2001). Spherical MSU-1 Mesoporous Silica Particles Tuned for HPLC. Advanced Functional Materials, 11(2), 129-135. http://dx.doi.org/10.1002/1616-3028(200104)11:2<129::AID-ADFM129>3.0.CO;2-W

Fagerlund, G. (1973). Determination of specific surface by the BET method. Matériaux et Construction, 6(3), 239-245. http://dx.doi.org/10.1007/BF02479039

Grün, M., Lauer, I., \& Unger, K. K. (1997). The synthesis of micrometer- and submicrometer-size spheres of ordered mesoporous oxide MCM-41. Advanced Materials, 9, 254-257. http://dx.doi.org/10.1002/adma.19970090317

He, Q. J., Shi, J. L., Zhao, J. J., Chen, Y., \& Chen, F. (2009). Bottom-up tailoring of nonionic surfactant-templated mesoporous silica nanomaterials by a novel composite liquid crystal templating mechanism. Journal of Materials Chemistry, 19(36), 6498-6503. http://dx.doi.org/10.1039/B907266G

Huang, L., \& Kruk, M. (2015). Versatile Surfactant/Swelling-Agent Template for Synthesis of Large-Pore Ordered Mesoporous Silicas and Related Hollow Nanoparticles. Chemistry of Materials, 27(3), 679-689. http://dx.doi.org/10.1021/cm5028749

Huo, Q. S., Feng, J. L., Schüth, F., \& Stucky, G. D. (1997). Preparation of Hard Mesoporous Silica Spheres. Chemistry of Materials, 9, 14-17. http://dx.doi.org/10.1021/cm960464p

Jun, S., Joo, S. H., Ryoo, R., Kruk, M., Jaroniec, M., Liu, Z., ... Terasaki, O. (2000). Synthesis of New, Nanoporous Carbon with Hexagonally Ordered Mesostructure. Journal of the American Chemical Society, 122(43), 10712-10713. http://dx.doi.org/10.1021/ja002261e

Kosuge, K., \& Singh, P. S. (2001). Rapid Synthesis of Al-Containing Mesoporous Silica Hard Spheres of 30-50 $\mu \mathrm{m}$ Diameter. Chemistry of Materials, 13(8), 2476-2482. http://dx.doi.org/10.1021/cm000623b

Kosuge, K., Kikukawa, N., \& Takemori, M. (2004). One-Step Preparation of Porous Silica Spheres from Sodium Silicate Using Triblock Copolymer Templating. Chemistry of Materials, 16(21), 4181-4186. http://dx.doi.org/10.1021/cm0400177

Kosuge, K., Murakami, T., Kikukawa, N., \& Takemori, M. (2003). Direct Synthesis of Porous Pure and Thiol-Functional Silica Spheres through the $\mathrm{S}^{+} \mathrm{X}^{-}{ }^{+}$Assembly Pathway. Chemistry of Materials, 15(16), 3184-3189. http://dx.doi.org/10.1021/cm030225j

Kresge, C. T., Leonowicz, M. E., Roth, W. J., Vartuli, J. C., \& Beck, J. S. (1992). Ordered mesoporous molecular sieves synthesized by a liquid-crystal template mechanism. Nature, 359, 710-712.

Liang, J. X., Zhang, X. K., Li, X., Huo, H. F., \& Wang, C. (2014). Preparation and Characterization of Ordered Mesoporous $\mathrm{SiO}_{2}$ Under Certain Acidity. Journal of capital normal university, 35(3), 25-29.

Meng, H., Xia T., George, S. J., \& Nel, A. E. (2009). A predictive toxicological paradigm for the safety assessment of nanomaterials. American chemistry society nano, 3(7), 1620-1627. http://dx.doi.org/10.1021/nn9005973

Nooney, R. I., Thirunavukkarasu, D., Chen, Y. M., Josephs, R., \& Ostafin, A. E. (2002). Synthesis of Nanoscale Mesoporous Silica Spheres with Controlled Particle Size. Chemistry of Materials, 14(11), 4721-4728. http://dx.doi.org/10.1021/cm0204371

Qi, L. M., Ma, J. M., Cheng, H. M., \& Zhao, Z. G. (1998). Micrometer-Sized Mesoporous Silica Spheres Grown under Static Conditions. Chemistry of Materials, 10(6), 1623-1626. http://dx.doi.org/10.1021/cm970811a

Sun, S. F., Li, X. Y., Nu, S. L., \& You, X. (1999). Immobilization and Characterization of â-Galactosidase from the Plant Gram Chicken Bean (Cicer arietinum). Evolution of Its Enzymatic Actions in the Hydrolysis of Lactose. Journal of Agricultural and Food Chemistry, 47(3), 819- 823. http://dx.doi.org/10.1021/jf980442i

Tanriseven, A., \& Doğan Ş. (2002). A novel method for the immobilization of $\beta$-galactosidase. Process Biochemistry, 38(1), 27-30. http://dx.doi.org/10.1016/S0032-9592(02)00049-3

Trofimova, E. Y., Grudinkin, S. A., Kukushkina, Y. A., Kurdyukov, D. A., Medvedev, A. V., Yagovkina, M. A., \& Golubev, V. G. (2012). Fluorescent monodisperse spherical particles based on mesoporous silica containing rhodamine 6G. Physics of the Solid State, 54(6), 1298-1305. http://dx.doi.org/10.1134/S1063783412060339

Tu, W. X., Sun, S. F., Nu, S. L., \& Li, X. Y. (1999). Immobilization of $\beta$-galactosidase from Cicer arietinum (gram chicken bean) and its catalytic actions. Food Chemistry, 64(4), 495-500. http://dx.doi.org/10.1016/S0308-8146(98)00141-1

Yang, L. M., Wang, Y. J., Sun, Y. W., Luo, G. S., \& Dai, Y. Y. (2006). Synthesis of micrometer-sized hard silica spheres with uniform mesopore size and textural pores. Journal of Colloid and Interface Science, 299(2), 823-830. 
Zhang, H. J., Wu, J., Zhou, L. P., Zhang, D. Y., \& Qi, L. M. (2007). Facile Synthesis of Monodisperse Microspheres and Gigantic Hollow Shells of Mesoporous Silica in Mixed Water-Ethanol Solvents. Langmuir, 23(3), 1107-1113. http://dx.doi.org/10.1021/la0625421

Zhang, X. Z., Le, Y. H., \& Gao, Z. (2001). Studies on 12-Tungstophosphoric Heteropolyacid Supported SBA-15 Catalysts. Journal of advanced chemistry, 22(7), 1169-1172.

Zhao, S. L., Zhang, Y. J., Sun, G. D., \& Zhai, Y. C. (1999). The Characterization and Synthesis of Mesoporous Molecular Sieve MCM-41 by Microwave Radiation. petrochemical industry, 28(3), 139-141.

Zhu, S. J., Meng, Q. G., Wang, L., Zhang, J. H., Song, Y. B., Jin, H., ... Yang, B. (2013). Highly Photoluminescent Carbon Dots for Multicolor Patterning, Sensors, and Bioimaging. Angewandte Chemie International Edition, 52(14), 3953-3957. http://dx.doi.org/10.1002/anie.201300519

\section{Copyrights}

Copyright for this article is retained by the author(s), with first publication rights granted to the journal.

This is an open-access article distributed under the terms and conditions of the Creative Commons Attribution license (http://creativecommons.org/licenses/by/4.0/). 